https://doi.org/10.18485/cosic_dobrica.2018.ch15

$821.163 .41^{\prime} 255.4=161.1$

821.163.41.09-31ћосић Д.

\author{
ДРАГАНА М. КЕРКЕЗ* \\ Универзитет у Београду \\ Филолошки факултет
}

\title{
ПРЕВОД РОМАНА КОРЕНИ НА РУСКИ ЈЕЗИК
}

\begin{abstract}
У раду се анализирају веома уски сегменти из превода романа Корени Добрице Ћосића на руски језик: реченице у којима је у тексту оригинала писац употребио прилог оgјеgном. На основу извршене анализе аутор долази до закључка да је у српском савременом језику оправдано разликовати три лексеме: ogjegном1, одјеgном2, олједном3.
\end{abstract}

Кључне речи: евалуација превода, неочекиваност, лексичка средства, прилог, семантичка компонента, темпоралност.

0. Србија је одувек била земља српског сељака, те се може рећи да ко познаје душу српског сељака, познаје и душу Србије.

Међу српским писцима који су веома добро познавали и описали сопство српског сељака свакако посебно место заузима Добрица Ћосић, који је, како каже Борислав Михајловић, „отворио [...] срце Србије, загледао се у њега и није устукнуо" (Михајловић 1971: 189), показао да као свој кожух познаје ову Србијицу и да је кост српског сељака тврђа од старе кленовине (Ћосић АСК: 4).

Тема овог рада јесу одређени сегменти превода на руски језик једног од првих Ћосићевих дела, његов роман Корени, који Р. Ивановић (2014: 661) назива „ембрионом нове књижевне грађевине, посвећене породичној хроници Аћима Катића, његових синова и унука", а Ј. Деретић (2007: 159) одређује као поетски психолошки роман, умногостручене субјективне перспективе, у којем се драматични судари међу личностима осветљавају из више углова, са становишта свих актера радње".

Чињеница да, с једне стране, датој лексеми приступамо као једном од маркера грамеме неочекиваности, а с друге стране, да анализирамо ваљаност превода, условила је еклектичан теоријско-методолошки приступ.

\footnotetext{
*draganakerkez@hotmail.com
} 
1. Као што знамо, Ћосић Корене објављује 1954. године, али је на превод овог романа (за разлику од превода романа Далеко је сунще $e^{1}$ ) руски читалац чекао скоро три деценије: године 1983. издавачка кућа

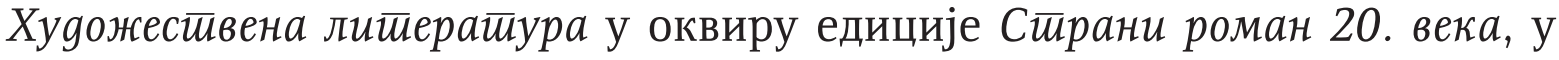
преводу Т. П. Попове ${ }^{2}$ објављује Корене на руском.

1.1. Превод књижевноуметничког дела представља посебан вид преводилачке делатности која у односу на стручни - у терминологији В. Н. Комисарова (Комиссаров 1995: 20) информатиивни - превод истовремено поседује са њим како заједничке, тако и разликовне елементе. С једне стране, према правилном запажању руског хиспанисте и теоретичара превода В. С. Виноградова, циљ превода није подешавање текста у односу на нечију перецепцију, већ очување садржаја, функције, стилогених, стилистичких, комуникативних особености оригинала (Виноградов 2001: 20). С друге стране, књижевноуметнички текст поседује низ специфичних карактеристика у односу на остале функционално-стилске типове текста, међу којима се као доминанта издваја уметничко-естетска или поетска функција, услед чега се превод књижевноуметничког дела може сматрати самосталним делом које је саздано на језику превода (Комиссаров 1990: 95)³. На основу реченог јасно проистиче закључак да је преводилац књижевноуметничког дела стално суочен са двама, у извесном смислу супротстављеним начелима: начелом прецизности и начелом креативности. ${ }^{4}$

1.2 Осим тога, књижевна дела јесу национално, културно и временски маркирана, што од преводиоца изискује умешност у решавању питања лакунарности.

${ }^{1}$ Превод романа Далеко је сунще појавио се у руским књижарама (тачније, књижарама Совјетског Савеза) 1956. године. Осим тога, према нашем увиду, на руски су

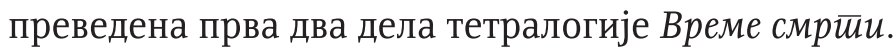

${ }^{2}$ Татјана Протогеновна Попова, познати преводилац српских али и других писаца са простора бивше Југославије. Од 1951. па све до 1989. радила је на Катедри за словенске језике при МГУ.

${ }^{3}$ Овакав став Комисарова кореспондира са мишљењем Ј. Левија, који превођење књижевноуметничког текста одређује као репродуктивну уметност (Levi 1982: 71).

${ }^{4}$ Управо због ове и овакве преводу књиженоуметничког дела својствене антиномије Г. Гачечиладзе сматра да се читава историја ове врсте превода у пракси налази на размеђи двају принципа: садржински тачног али уметнички недостатног превода, с једне стране, и уметнички пуновредног али далеког од оригинала. Међутим, ако је теоретски ова два принципа лако синтетисати и за идеал прогласити превод који је садржински тачан и уметнички адекватан, примећује даље Гачечиладзе, у пракси је таква синтеза немогућа (Гачечиладзе 1980: 81). Ово је био један од основих разлога што је Г. Гачечиладзе био ватрени присталица слободног превода, што нас пак доводи до новог проблема, а то је питање превода и интерпретације, чиме се ми овде нећемо бавити, али упућујемо на неке од радова у којима се дати проблем разматра (ФЧ 2001). 
Сагледавајући текст романа Корени, може се закључити да је преводилац имао далеко мање изазова када је у питању транспоновање артефаката из свакодневног живота српског сељака на руски језик (као што су биваци, вајати и сл.) или пак реалија карактеристичних за живог Србије с краја XIX века (попут историјског покрета 'обреновићеваца'), али је зато далеко више напора морао уложити при транспоновању поетизованог и ауторским метафорама богатог Ћосићевог текста.

2. Међутим, тема за коју смо се ми одлучили неће се тицати ни питања лакунарности, ни уметничке ипостаси текста. Наиме, предмет анализе овог рада, а самим тим и еваулације превода на руски језик биће само један веома узак сегмент романа Корени: превод реченица у којима фигурира прилог оgјеgном.

2.1. Дати прилог је привукао нашу пажњу као могући маркер неочекиваности која представља једну од грамема функционално-семантичке категорије очекиваности/неочекиваности ${ }^{5}$.

Радна хипотеза од које смо пошли гласи: прилог оgјеgном може али не мора бити маркер дате грамеме (уп. са супротним закључком изнетим у Ристић 1990: 65).

Наведену хипотезу ћемо проверити тако што ћемо упоредити одабране реченице из изворника са њиховим преводом на руски језик. Упориште оправданости оваквог приступа нашли смо у становишту да се садржаји скривени у језику књижевног дела јасније и изразитије уочавају на фону његовог превода, као што и појаве у неком језику бивају видљивије ако се посматрају из перспективе другог језика (Радић-Дугоњић 2003: 322).

2.2. У двојезичним руско-српским речницима као најближи еквивалент прилога оgјеgном наводи се прилог вgруі̄.

О руском вgруі̄ и његовом месту у систему руског језика доста је писано, као и о његовој функцији у књижевном тексту ${ }^{6}$.

${ }^{5}$ Помоћу маркера дате ФСК говорно лице актуелну ситуацију одређује као интегрисани или неинтегрисани део своје језичке слике света, а инваријанто значење грамема ФСК очекиваности/неочекивности може се изразити на следећи начин:

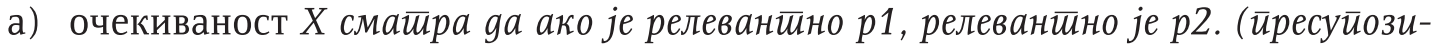
иија) Х йврgи gа је релеванйно р2. (асери,ија)

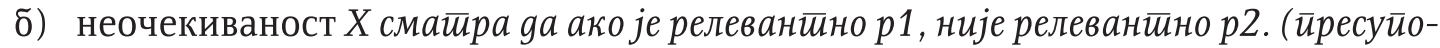
зииија) X ииврgи gа је релеванйнно р2. (асериија) (Керкез 2012: 459)

${ }^{6}$ Не можемо а да не поменемо рад В. Н. Топорова, који је писао о посебном значају речи са значењем изненадности, необичности код Достојевског, који је, између осталог, указао на чињеницу да су сви текстови Достојевског 'засићени' речју вgрyі̄. Топоров је установио да се у Злочину и казни реч вgруі употребљава чак 560 пута и закључио, између осталог, да се дата лексема користи као нека врста облигаторног квалификатора ситуације, што га приближава некој врсти члана (Топоров 1995 : 198). 
На основу 15 прегледаних дела српских писаца7 ${ }^{7}$ може се рећи (свакако не у смислу тврдње већ у смислу претпоставке) да српски писци мање воле прилог ogjegном но руски писци прилог вgруі. По фреквентности употребе прилога оgјеgном на првом месту је И. Андрић, у чијем роману На Дрини ћуйрија прилог оgјеgном срећемо безмало 70 пута, одмах затим следе Ћосићеви Корени, у којима се дати прилог среће 35 пута, а тек нешто мање се исти прилог среће у роману M. Селимовића Дервиш и смрй (33 употребе). С друге стране, у Пекићевом Траїању за злайним руном или Сеобама Црњанског прилог оgјеgном употребљен је само једанпут. О ређој употреби прилога оgјеgном у српском него при-

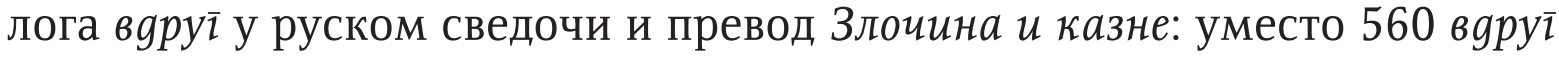
ogjegном се појављује мање од 200 пута.

2.3. Разлика у фреквентности употребе прилога оgјеgном у српском језику и прилога вgруі̄ у руском језику могла би се делимично објаснити и њиховим неједнаким дискурсивним потенцијалом.

Дискурсивна функција прилога вgруі̄ може бити двојака: наративна (ништа претходно није указивало на актуелну ситуацију) и функција увођења хипотезе (која може а не мора да се оствари: A вgруі̄ он прuegem?) (Шмелев 2002: 410), док српско оgјеgном може имати само једну од ових двеју функција - наративну.

2.4. Прилог оgјеgном у оригиналу употребљен је 35 пута, међутим, даље у тексту размотрићемо свега 9 реченица, будући да се у тексту на руском језику преводилац чак 26 пута одлучио да значење промене ситуације изражене у српском језику помоћу лексеме оgјеgном изрази руском лексемом вgруг. Од преосталих 9 реченица по једном срећемо прилоге сразу, мгновенно, тотчас, три пута прилог внезапно, два пута се преводилац послужио стратегијом или трансформацијом изосйављања, док је у реченици коју ћемо навести као први пример преводилац употребио фразеологизам стать как вкопанньй

${ }^{7}$ Осим наведених, прегледана су следећа дела: Г. Божовић, Косовске йриче; Д.

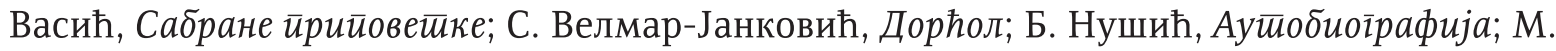
Пупин, Og йашъкака gо научењака; С. Ранковић, Прийоветике; И. Секулић, Кроника йаланачкої іорбља; С. Сремац, Пой Ћира и йой Сиира; Б. Станковић, Божји љуgи; Б. Ћопић, Баштиа сљезове боје и Орлови рано летее.

${ }^{8}$ Иако се у српском фразеолошком корпусу среће структурно и семантички истоветан поредбени фразеологизам ( $\bar{u} а \bar{u} u$ као укойан), у литератури на руском језику дато поређење сматрају изворно руским. Настанак поредбеног фразеологизма стать как вкопанный повезује се са уредбом из времена руског цара Алексија Михајловича. Дату уредбу цар је донео 1663. године и њом одредио да се као једна од мера строгог кажњавања има примењивати укопавање тела кривца у земљу све до главе (СРФ 2001: 84). 
На основу лексикографских дескрипција ${ }^{9}$ посматраног прилога у речницима савременог српског језика проистиче да се могу разликовати две лексеме ${ }^{10}$ : ogjegном1 и оgјеgном2.

Ogjegном1 (према лексикографској грађи) улази у синонимски ред

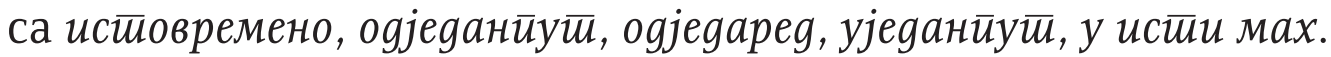

Прилог ogjegном2 улази у синонимски ред ${ }^{11}$ који чине прилози изнебуха, изненаgа, наіло, найрасно, найречаи, ненаgно, оgјеgанйуй, оgјеgа-

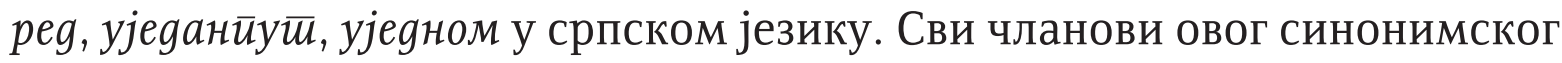
реда могу се окарактерисати као експлицитни маркери садржаја $\bar{u} о-$

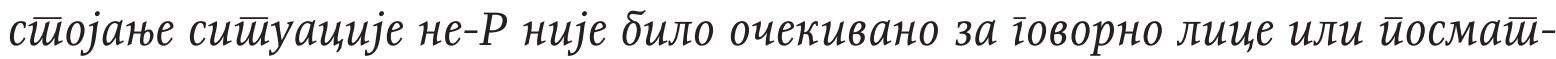

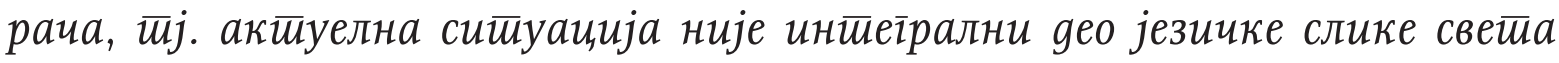
$\bar{\imath} о в о р н о \bar{\imath}$ лии, и, из чега следи да семантички садржај 'актуелна ситуација није интегрални део језичке слике света говорног лица' чини део језгреног или импликационог значења посматране језичке јединице. ${ }^{12}$

2.5. Управо у овом значењу употребљен је посматрани прилог у примерима 1-3.

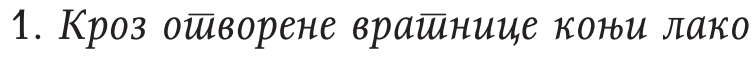

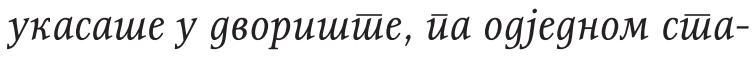
gome каo ga ygapume y 3 g.
В открытые ворота во gвор легко влетели сани. Кони стали как вкопанные, буgто налетели на збор.

Уколико прихватимо да значење прилога оgјеgном2 можемо па-

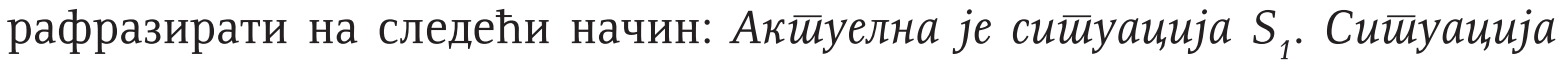

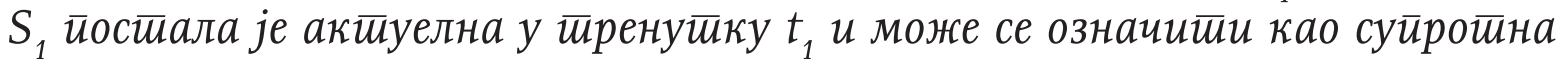

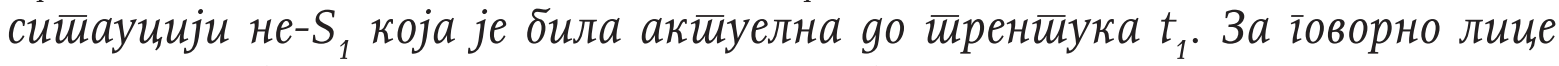

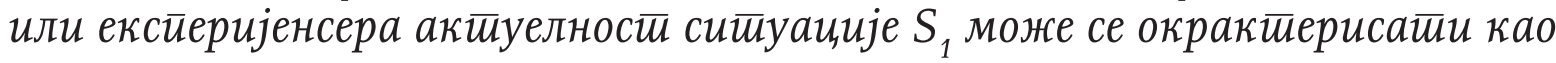

${ }^{9}$ Ogjegaнūy $\bar{u}$, ogjegapeg и ogjegном прил. 1. у исто време, истовремено: дати, купити више ствари. 2. неочекивано, изненада: удари киша, му позли. (РМС 2007: 859).

${ }^{10}$ Под лексемом подразумевамо реч у одређеном значењу са свим својствима (семантичким, прагматским, комуникативно-прозодијским, синтагматским, синтаксичким, фонетским и др.) која су иманентна датој лексеми (Апресјан 1999: XXII; 2009: 432). „Именно лексема, а не слово, является реальной лексической единицей языка, потому что в норме каждое многозначное слово используется в высказывании в каком-то одном из своих значений. В отличе от значения, лексема - многосторонняя единица языка: у нее есть означающее (фонетическая оболочка), означаемое (значение) и синтактика (особенности сочетаемости)" (Апресјан 1999: XXII).

${ }^{11}$ Следећи Д. Гортан-Премк, разликујемо синонимски низ и синонимски ред. Синонимски низ чине лексеме са истом референцијалном вредношћу, док у састав синонимског реда улазе лексеме са сличном референцијалном вредношћу (Гортан-Премк 2004: 141).

${ }^{12}$ О језичким јединицама као експлицитним и имплицитним вербализаторима одређеног значења, као и о разлици између имплицитног и импликационог значења писали су, између осталих, А. В. Бондарко (Бондарко 2008: 34), Н. Ф. Алефиренко (Алефиренко 2005: 201). 


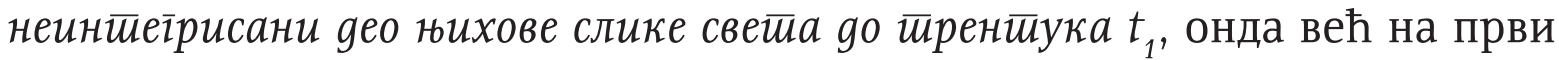
поглед видимо да за разлику од оригиналног текста у ком се помоћу лексеме оgјеgном2 преноси информација о брзој и ничим најављеној промени ситуације, превод на руски језик садржи наглашенију експресивно-емотивну конотацију коју са собом носи фразеологизам сmamь как вкопанныц̆. Ова доданта експресивно-емотивна конотација проузрокована је следећим: експресивност представља једну од основних особености фразелогизама (Мокиенко 1989: 5; Мршевић-Радовић 2008: V; Вуловић 2015: 25), док конкретни фразеологизам представља једну од оних фразеолошких јединица којима се вербализује емоција изненађења и/или страха ${ }^{13}$.

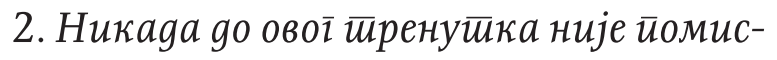

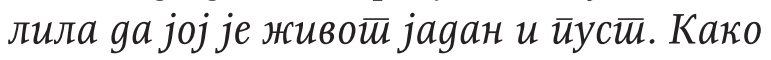
јој оgјеgном саgа нишйа не значи шито је їазgарии, у кући у којој йола села наяничи и служи.
Ни разу вплоть gо этой минуты она не подумала о том, ито жизнь ее - горька и пуста, и то, что она хозяйка дома, на который работает gобрая половина села, ровно ничего не значит.

У примеру бр. 2 преводилац неадекватним препознавањем значења друге реченице и испуштањем прилога ogjegном допушта још грубљу омашку - у потпуности мења значење овог одломка: док Ћосић реченицом Како јој оgјеgном саgа нишйа не значи шйо је їазgарии, у кући у којој йола села наgничи и служи указује на промену унутрашњег стања своје јунакиње за коју њен социјални статус у властитим очима у тренутку губи важност коју је имао до тада, преводилац у потпуности, тако да кажемо, брише информацију о унутрашњем емотивном преврату који се одигравао унутар јунакиње и руском читаоцу саопштава следеће: јунакиња раније није била свесна чињенице да јој је живот пун јада и испразан, а то што је газдарица куће за коју пола села надничи и служи иначе ништа не значи.

Погледајмо одмах и следећи пример:

\section{3. По Вукашину се оgјеgном сиивряла језа.}

По коже пробежали мурашки.

Метафору коју срећемо у овој реченици (стиврgла се језа) једна је од многобројних ауторских метафора којима је богат текст романа Корени. Ћосићева метафора се терминима Д. Кликовац може одредити као метафорички пренос типа 'емоција је материја' (Кликовац 2004: 207). Преводилац пак користи фразеологизам мурашки иробежали у осно-

${ }^{13}$ Потврду за то да се и поредбени фразеологизам стиайи као укойан може повезати са емоцијом изненађења и/или страха налазимо, између осталог, у раду Kovačević, Ramadanović 2016: 520. 
ви ког лежи други принцип метафоричке концептуалиције 'емоција је биће' (уп. Кликовац 2004: 209). Наравно, ауторске метафоре су понајтеже за преводиоца и то што се преводилац одлучио за решење која је већ у систему руског језика није спорно.

Пажњу привлачи друго. Наиме, у овом примеру глагол свршеног

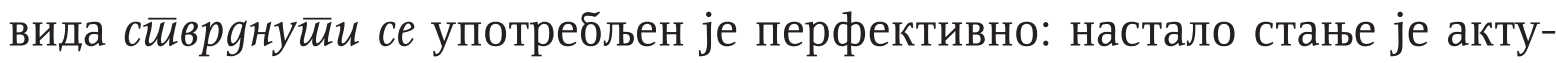
елно и у тренутку говора или референтне временске тачке (Падучева 1996: 153), док прилог о gјеgном има функцију минимализације времена настанка промене.

Осим што помоћу прилога оgјеgном крајње сужава време трансформације стања свог јунака, Ћосић помоћу њега наглашава саму промену, те се из те перспективе лексема оgјеgном може посматрати као интензификат, тј. као лексема која у својој семантичкој структури садржи компоненту 'веома'.

Управо та компонента 'веома' била је потребна Ћосићу како његов читалац не би остао равнодушан. Писац не само да жели да читалац обрати пажњу на насталу промену већ да та промена на њега остави јак утисак (уп. Родионова 2005: 159).

Резултат преводиочевог решења По коже пробежали мурашки је сасвим друга слика. Промена до које је дошло није актуелна у односу на референтну временску тачку: процес је трајао кратко и завршио се, тј. са аспекта акционалне модификације глагол пробежайь можемо окарактерисати као анулирани резултат - стање које је било наступило, кратко трајало, па је самим тим ефекат његовог резултата сведен на нулу (Плунгян 2001: 69). ${ }^{14}$

Како у примеру бр. 2 , тако и у примеру бр. 3 Ћосић помоћу прилога ogjegном исказује наглу промену стања својих јунака. Изостављањем прилога или било ког другог језичког средства за вербализацију овакве промене стања преводилац занемарује битне семантичке компоменте реченице 'актуелно стање ничим није било наговештено' и 'до промене стања дошло је у веома кратком року'. Пренебрегавањем минимализације времена, тј. изоставањем одговарајућег маркера неочекиване и брзе промене стања, преводилац мења и ритам текста, јер управо захваљујући прилогу оgјеgном Ћосић убрзава темпо свог приповедања (уп. Топоров 1995: 198). На тај начин графичка пројекција Ћосићевог оригиналног текста имала би вид линије са израженом амплитудом (уп. Виноградов 1976: 112), док бисмо преводиочево решење могли представити у виду праве. Самим тим преводилац мења емотивну интенционал-

14 Узевши у обзир све речено, чини нам се да би правомерније решење било следеће: Вgруг Вукашина охватила леgенящая/холояная жуть. 
ност Ћосићеве реченице те руском читаоцу онемогућава да правилно схвати пишчеву идејно-уметничку замисао.

Наравно, било би погрешно свести функцију прилога оgјеgном на функцију минимализације времена и маркера нагле промене стања, будући да дати прилог у свим наведеним примерима има и функцију семантичке копче надреченичне целине, тј. модификатора-конектора ${ }^{15}$.

Дакле, премда је изосйављање легитимна преводилачка стратегија, њој се може прибећи једино у случају када речи и изрази који постоје у оригиналном тексту нису неопходни за његово правилно разумевање, те стога, у свим проанализираним примерима, њена примена није оправдана.

2.6. У наредном делу рада предмет анализе јесу реченице у којима преводилац као семантички еквивалент употребљава руске прилоге сразу, тотиас, мгновенно.

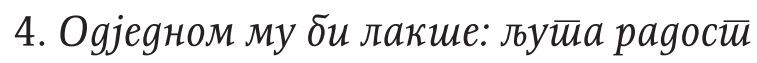
разли му се йо жилама.

5. Каиеейан се усиљено насмеја, али му og Аћимової йоїлеgа смех оgјеgном слеие с лииа и он више замишљено нет̄о сиироїо рече: - Знаш ли шйа оїлашује звоно?

6. И он одједном, сав ойијен нечим шито се не оgређује у свестии, нечим шито је ван юе, изіуббен и расуй у йрајању

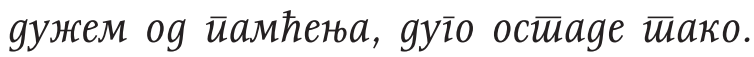
Онда се йолако врайи себи.
Сразу как-то полегчало: жгучая разлилась по жилам.

Уездный начальник натужно засмеялся, но поg Аиимовым взгляgом смех тотиас же слетел с его лии, и, и он скорее заяумииво, чем строго gобавил: - Ты понимаешь, почему звонят колокола?

И, мгновенно захмелев от чегото не подающегося осмыслению, лежащего вне сознания, потерял ошущение времени и растворился в его бесконечности, которая глубже, чем память, и долго просияел так без движения. Потом меgленно пришел в себя.

Примери бр. 4-5 занимљиви су, осим са аспекта евалуације превода, са аспекта семантике прилога оgјеgном у српском језику.

У семантичкој структури прилога оgјеgном увек је присутна семантичка компонента 'време'. Међутим, док је у примерима 1-3 архисема прилога оgјеgном2 'неочекиваност', а временска компонента чини диференцијалну сему, у примерима бр. 4 и 5 временска компонента чини семантички центар лексеме. При томе временска компонента има

15 Термин модификатор-конектор преузели смо од И. Прањковића, који под њима подразумева прилоге који истовремено функционишу као модалне речи и као везна средства на нивоу текста (Pranjković 2002: 27). 
значење пунктуалног чина: време у ком се процес извршио не може се поделити на појединачне интервале већ на временској оси представља тачку. Другим речима, процес који се извршио јесте појединачан, не може бити рашчлањен на више простих ситуација (уп. Пипер 2008: 403), нити има наспрам себе симултану радњу. Уколико бисмо покушали да нпр. у реченици Кайейан се усиљено насмеја, али му оg Аћимової йойлеgа смех одјеgном слейе с лии, и он више замишљено неі̄о сйроі̄о рече: -Знаш ли шйа оілашује звоно? прилог оgјеgном заменимо прилогом исииовремено, таква реченица тешко да би могла бити прихватљива. За разлику од ове, у реченици Осамостиаљиване занашиа ... није извршено ... о ојеgном у свима занайима. Пов. (РМС 1971: 41) супституција прилога оgјеgном и исшиовремено у потпуности је могућа.

Стога сматрамо да би било исправно разликовати не две, већ три лексеме у којима семантичка компонента 'време' има различита значења:

- ogjegном1 - време трајања одређеног процеса је максимално кратко, тачније реч је о пунктуалном чину;

- ogјеgном2 - време појављивања процеса је веома кратко;

- ојеgном3 - време трајања одређеног процеса текло је паралелно са временом трајања другог процеса (синоним типа исйовремено).

Пример бр. 6 пак захтева коментар који изискује да дамо нешто

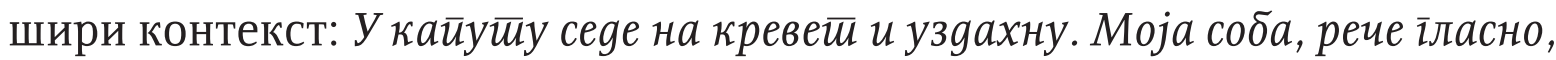
а зимски мирис воћа и сувогі ливаgскогі ивећа у венчићима на зияовима и

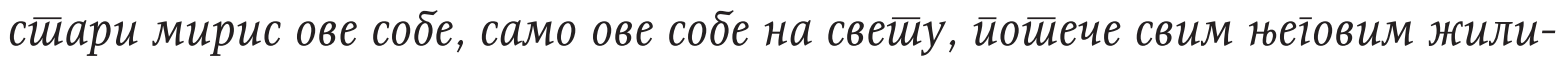

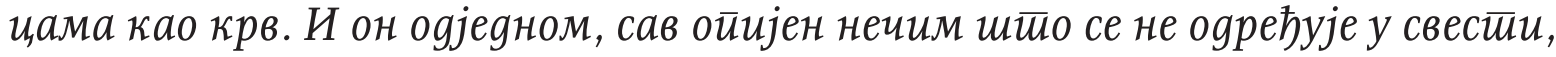

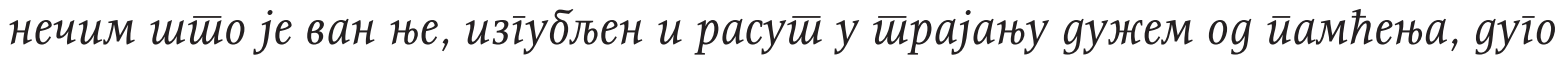

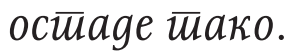

Наведени пример је по много чему особит. Са тачке гледишта евалуације превода решење на руском језику може се окрактерисати као нетачно, будући да преводилац неправилно одређује семантику, а самим тим и сферу деловања прилога ogjegном. Временска компонета прилога ogjegном у Ћосићевој реченици нема значење 'време трајања одређеног процеса јесте максимално кратко', већ 'време појављивања процеса је веома кратко' и има ранг диференцијалне семе. Другим речима, реч је о лексеми оgјеgном2.

Осим тога, у већини случајева прилог ogjegном2 упућује на неочекивану промену до које је дошло у кратком временском периоду, карактерише актуелну ситуацију у целини. Овде пак је неочекивана дужина трајања промене: оно што је претходило није указивало да ће Ћосићев јунак бити дуго у таквом стању, тј. даје се карактеризација не актуелне 
ситуације у целини, већ само једног њеног сегмента: времена трајања. На основу реченог, може се извести закључак да прилог ogjegном2 може имати како широку, тако и уску сферу деловања ${ }^{16}$.

2.7. На крају је остало да кажемо неколико речи о примерима у којима се преводилац одлучио за преводни еквивалент внезапно.

7. Уживао је, їлеgајући је кроз иро-

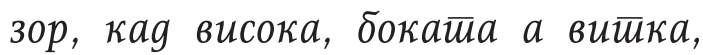
лако као усираван вал зайлови gво-

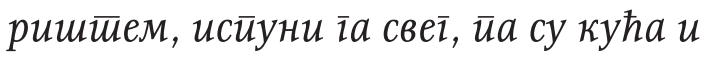
зіраяе и јасенови мали, као иірачке;

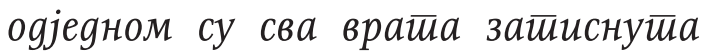
юоме, а руке немирне, као gа расаg cage.

8. Вукашин сйоји уз ирозор, вране іачу на јасеновима, луйају крилима, gрвеће као gа йаgа кроз майлу, ogjegном йосечено. Он се ирже и окрену,

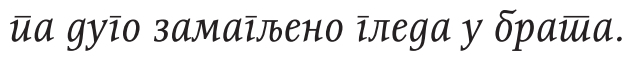

9. У берачкој вечери, Симкин смех, злобан и раяостиан, gуі̄о се вије и беласа у жућкастиој иммини велике кухиње, [...] а іррубе руке сйушйају кашике йоpeg заіризака йpoje u све очu ūagajy $\bar{u} о$ юој која стиоји више юихових ілава, висока и усиравна, слеђена gуіууљастиа лии, о, оједном йосииђена и смехом и Тишином йосле юеїа.
Он любовался, гляяя в окно на невестку: высокая, бокастая, но стройная, она легко пльла по gвору, буgто крутая волна, так ито и дом, и остальные постройки, и ясени суелались маленькими - просто оетские игрушки; внезапно все gвери оказались занятыми ею, а руки быстро сновали, словно она высанивает рассаgу.

Вукашин стоит у окна, воронь раскаркались на ясенях, машут крыльями, деревья будто валятся в туман, внезапно сгорбленные по корень, он вздрагивает, оборачивается и долго, невияящим вгляgом смотрит на брата.

Симкин смех, злораяный и сиастливый, gолго кружил и переливался в желтом полумраке огромной кухни, [...] грубые руки разом опустили ложки возле куска кукурузного хлеба, и все глаза устремились к нец̆, стоящей наg ними, высокой и стройноц̆, с продолговатым, застывшим лииом, а она внезапно устьлилась и собственного смеха, и послеgовавшей за ним тишины.

Како у примеру бр. 7, тако и у примерима бр. 8 и 9 могуће би било извршити супституцију прилога оgјеgном прилозима неочекивано и изненаgа.

${ }^{16}$ Када говоримо о сфери деловања ових лексема, имамо заправо у виду питање њихове способности да карактеришу целокупну ситуацију (шира сфера деловања) или само неки њен поједини део (ужа сфера деловања) (уп. Левонтина НОССРЯ 2002: 216). 
Сви наведени прилози припадају начинским прилозима ${ }^{17}$ уколико се сложимо са П. Пипером да начин представља локализацију акције у извесном облику њене реализације који је одређен неком карактеристичном особином у датом тренутку издвојеном на основу критеријума релевантности, као и да се прилози из наведених реченица могу супституисати истим заменичким (начинским) прилогом 'тако' (Он шио pagu चако). Онда се можемо сложити и да прилог ogjegном јесте начински у смислу да појам начински упућује на његову категоријалну семантику (Piper 1983: 100-101). ${ }^{18}$

Ипак, група начинских прилога семантички је разнородна. С. Ристић је прилоге типа ogjegном одредила као начинске прилоге са интегралном семом темпа. Даље се дати прилози деле на две основне парадигме: прилози којима се исказује начин вршења радње и прилози који означавају начин појављивања радње, стања, процеса (уп. Ристић 1990: 56-58; 2008: 402). У обе парадигме прилога темпа односи међу јединицама регулисани су семама убрзаног и успореног темпа. Слажући се да ogjegном 2 јесте прилог који означава начин појављивања радње, стања и процеса, одредићемо га као начинске йрилоіе брзе ирромене сйана ${ }^{19}$ чије бисмо инваријатно значење парафразирали на следећи начин: До йре-

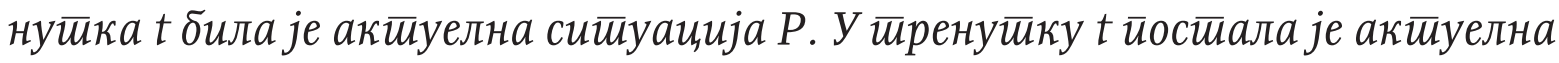
сийуаи, ија не-Р.

Уколико узмемо тријаду неочекивано-изненаga-ogjegном уочљиво је да прилози неожияанно/неочекивано првенствено карактеришу актуелну ситуацију као неодговарајућу очекиваној. Разлику између њих чини темпорална компонента која није интегрална прилогу неочекивано, прилог изненаgа је углавном чува, док је у семантичкој структури прилога ogjegном темпорална компонентна недвојбено изражена. Речено ћемо илустровати примерима у којима значење брзе промене стања није релевантно.

Уп. Милан неочекивано сазнаgе gа Пейар gолази.

Милан изненаgа сазнаgе gа Пейар gолази.

Милан одјеgном сазнаgе gа Пейар gолази.

${ }^{17}$ Када је реч о томе којој групи припадају наведени прилози, литература нам даје различите одговоре: за једне су то временски (нпр. Панков 2009, Pintarić 2011), за друге начински прилози (Piper 1983, Ристић1990).

${ }^{18}$ Овако широко начин поима и С. Ристић, аутор до сада најобимније студије о начинским прилозима код нас (Ристић 1990). Преглед различитих класификација прилога у руској граматичкој традицији в. О. И. Глушченко 2005a, а о историји питања класификација одредбених прилога в. Глушченко 2007. О томе како су прилоге видели српски (и хрватски) граматичари и лексикографи в. нпр. Грицкат 1983, Ристић 1990.

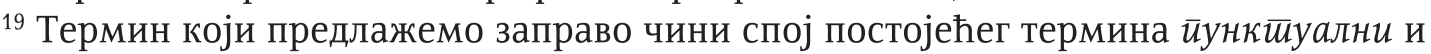
термина ирилози за ирромену сйања, који је предложила М. Ивић (Ivić 1995: 299). 
3. На основу реченог, можемо извести следеће закључке:

$>$ Основано је разликовати лексеме оgјеgном1, ogјеgном2, ogjegном3. Лексема оgјеgном2 припада групи прилога које ћемо именовати као начинско-йемйоралне, за разлику од лексема ogјеgном1 и оgјеgном3, који се могу одредити као иеммйоралноначински прилози.

$>$ Прилог ogјеgном2 може бити супституисан прилозима неочекивано и изненаgа. Међутим, док се темпорална компонента налази на далекој периферији семантичког поља прилога неочекивано, када говоримо о прилогу оgјеgном 2 и прилогу изненаgа, дата семантичка компонента део је доцентралне и ближе периферије њиховог семантичког поља.

$>$ Експлицитно лексичко средство маркирања грамеме неочекиваности представља само лексема оgјеgном2.

\section{ИЗВОРИ И ЛИТЕРАТУРА}

Божовић, Григорије. Косовске ириче. Антологија српске књижевности, „n.d.” Васић, Драгиша. Сабране йрийовейке. Антологија српске књижевности, „n.d.” Велмар-Јанковић, Светлана. Дорћол. Антологија српске књижевности, „n.d.” Нушић, Бранислав. Ауш̄обиоірафија. Антологија српске књижевности, „n.d.”

Пупин, Михајло. Og йашњака gо научењака. Антологија српске књижевности, "n.d."

Ранковић, Светолик. Прийовейке. Антологија српске књижевности, „n.d.”

Секулић, Исидора. Кроника йаланачкої іорбља. Антологија српске књижевности, „n.d."

Сремац, Стеван. Пой Ћира и ӣoū Сūupa. Антологија српске књижевности, „n.d.” Станковић, Борисав. Божји љуgu. Антологија српске књижевности, „n.d.”

Ћопић, Бранко. Башйа сљезове боје. Антологија српске књижевности, „n.d.”

Ћопић, Бранко. Орлови рано лешее. Антологија српске књижевности, „n.d.”

Ћосић, Добрица. Корени. Антологија српске књижевности, „n.d.”

Чосич, Добрица. Корни. Москва: Художественная литература, 1983.

Andrić, Ivo. Na Drini ćuprija. Veb. „n.d.”

Pekić, Borislav. U traganju za zlatnim runom. Veb. „n.d."

Selimović, Meša. Derviš i smrt. Srboljub75, Veb. „n.d.”

Алефиренко, Николай Федорович. Спорные проблемы семантики. Москва: Гнозис, 2005. Шт.

Бондарко, Александр Владимирович. „Категоризация семантики в системе грамматики". Бондарко А. В. и Шубик С. А. (отв. редакторы). Категоризаиия семантики. Санкт-Петербург: Наука, 2008. Шт. 
Виноградов, Виктор Владимирович. „К морфологии натурального стиля: (Опыт лингвистического анализа петербургской поэмы «Двойник»)". Виноградов В. В. Поэтика русской литературы: Избранные труgы. Москва: Наука, 1976. 101-140. Шт.

Виноградов, Венедикт Степанович. Ввеgение в перевоgовеgение (общие и лексические вопросы). Москва: Издательство института общего среднего образования РАО, 2001. Шт.

Вуловић, Наташа. Срйска фразеолоїија и релиіија. Линівокулйуролошка исйраживања. Монографије 23. Београд: Институт за српски језик САНУ, 2015. Шт.

Гачечиладзе, Гиви Рожденович. Хуgожественный перевоg и литературные взаимосвязи. Москва: Советский писатель, 1980. Шт.

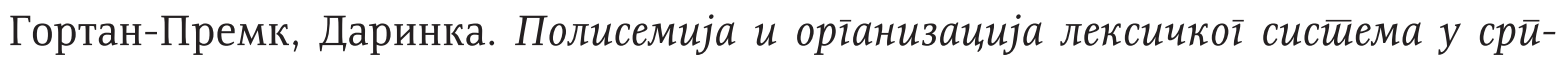
ском језику. Београд: Завод за уџбенике и наставна средства, 2004. Шт.

Деретић, Јован. Крайка истиорија срйске кюижевносиии. Нови Сад: Адреса, 2007. Шт.

Ивановић, Радомир. „Човек у трагичном судару са историјом. Ратна и антират-

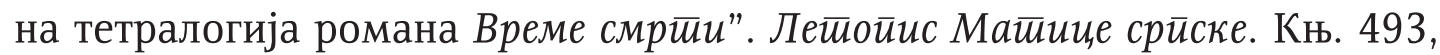
св. 5, 2014. $650-671$. Шт.

Ivić, Milka. „O prilozima za promenu (nekog prethodno uspostavljenog) stanja”. O zelenom konju. Novi lingvistički ogledi. Beograd: Slovograf, 1995. 298-304. Št.

Керкез, Драгана. „Претеритална времена и неочекиваност у српском језику (у поређењу са руским)". Зборник раяова са Међународної науиної скуйа оgржаної у Хериеті-Новом 20-23. айрила 2012. Никшић: Друштво чланова у Црној Гори, Одјељење за српски језик и књижевност; Нови Сад: Матица српска у Новом Саду, 2012. 459-468. Шт.

Kovačević, Barbara, i Ermina Ramadanović. „Primarne emocije u hrvatskoj frezeologiji”. Časopis Instituta za hrvatski jezik i jezikoslovlje, 42/2 (2016): 505-527.

Комиссаров, Вилен Наумович. Теория перевоgа (лингвистические аспекты): Уиебник яля институтов и факультетов иностранных языков. Москва: Высшая школа, 1990. Шт.

Levi, Jirži. Umjetnost prevođenja. Sarajevo: Svjetlost, 1982. Št.

Михајловић, Борислав. Кюижевни разі̄овори. Београд: Српска књижевна задруга, 1971. Шт.

Мокиенко, Валерий Михайлович. Славянская фразеология. Москва: Высшая школа, 1989. Шт.

Мршевић-Радовић, Драгана. Фразеолоі̄uја и национална кулйура. Београд: Друштво за српски језик и књижевност Србије, 2008. Шт.

Падучева, Елена Викторовна. Семантические исслеgования. Семантика времени и вияа в русском языке. Семантика нарратива. Москва: Языки славянской культуры, 1996. Шт.

Панков, Федор Иванович. Функиионально-коммуникативная грамматика русского наречия. Рукопис докторске дисертације одбрањене на Московском државном универзитету „М. В. Ломоносов”, 2009. 
Pintarić, Neda. „Komunikacijski prilozi i priložni odnosi u hrvatskom i poljskom jeziku". Südslavistik online, Nr. 3 (2011). Veb. 2. 8. 2017.

Piper, Predrag. Zamenički prilozi : (gramatički status i semantički tipovi). Radovi Instituta za strane jezike i književnosti. A. Jezičke studije, sv. 5. Novi Sad: Institut za strane jezike i književnosti, 1983.

Плунгян, Владимир Александрович. „Антирезультатив до и после результата”. Плунгян В. А. (отв. ред.). Исслеgования по теории грамматики. Вый. 1: Глагольные категории. Москва, 2001. 50-88. Шт.

Pranjković, Ivo. Hrvatska skladnja. Zagreb: Hrvatska sveučilišna naklada, 2002.

Радић-Дугоњић, Милана. „Прилог проучавању инваријантних и варијантних обележја концепата емоције у српском и руском језику (на материјалу романа „Сеобе” М. Црњанског и његовог руског превода)”. Сйил. Београд: 2003. 321-329. Шт.

Ристић, Стана. Начински ирилози у савременом срйскохрвайском книжевном је-

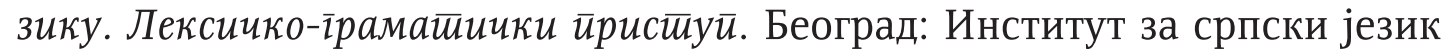
САНУ, 1990. Шт.

Ристић, Стана. „Прилог постепено као лексички квантификатор”. Јужнословенски филолої, LXIV (2008): 401-417. Шт.

Родионова, Светлана Евгеньевнаа. „Семантика интенсивности и ее выражение в современном русском языке". Бондарко А. В. (ред.). Проблемы функииональной грамматики: Полевые структуры. Санкт-Петербург: Наука, 2005. 150-166. Шт.

Топоров, Владимир Николаевич. Миф. Ритуал. Символ. Образ: Исслеgования в области мифопоэтического: Избранное. Москва: Издательская группа „Прогресс” - „Культура”, 1995. Шт.

Шмелев, Алексей Дмитриевич. Русский язык и внеязыковая gействительность. Москва: Языки славянской культуры, 2002. Шт.

Драгана М. Керкез

ПЕРЕВОД РОМАНА КОРЕНИ НА РУССКИЙ ЯЗЫК

\section{Резюме}

В данной работе анализируются предложения из романа Добрицы Чосича Корни, а именно предложения, в которых сербским писателем употреблено наречие ogjegном, и их перевод на русский язык. В конце автор приходит к выводу, что есть основания различать в сербскоя языке три отдельных лексемы: оgјеgном1, олјеgном2, олјеgном3. 